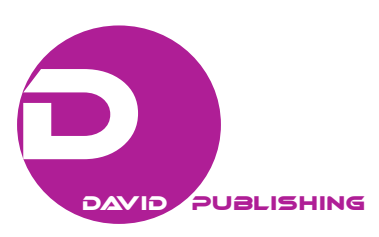

\title{
Transaction Costs of Entrepreneurs as a Deterrent of Housing Construction Development in Russia
}

\author{
Marina Yudenko, Nadegda Polovnikova, Igor Fedoseev \\ Saint-Petersburg State University of Economics, Saint-Petersburg, Russia
}

\begin{abstract}
Nowadays realization process of investment and construction projects is not always effective because of imperfection of institutions regulating construction, high investment risks and, as a consequence, increase transaction costs. The facts of the objective existence of transaction costs in the economy, including housing construction, are researched in the article. We have determined that the transaction costs significantly affect the cost of construction, reduce profit entrepreneurs, and indirectly increase the shortage of housing in Russia. Such parts of modern economics as neoclassical economics and institutional economics are methodological basis of the paper. Logical, economic and legal (institutional), socio-economic approaches were used during the research of transaction costs function. The authors used the complex of ideas and different methods of sociological and economic analysis that allowed deepening the importance of institutional state regulation of business activity in housing construction area. The classification of transaction costs creation was worked out; this model unlike well-known models considers the most important parts of transaction costs which really exist in business activity of construction companies nowadays; implementation of the model allows calculating and predicting this kind of costs in business. Recently Russian government returns to the questions about efficiency of production (increase of labor productivity, efficiency and profitability of production), therefore attention to the reduction of transaction costs is going to increase profits and efficiency.
\end{abstract}

Keywords: housing construction, model of transaction costs, institutional factors, opportunism, efficiency

\section{Introduction}

A number of scientists in Russia study institutional approach to entrepreneurship. Scientific interest appears here as institutions cut down transaction costs that is significant for entrepreneurs. The shortest way to do it is to reduce economic uncertainty establishing steady rules of behavior. Object of the analysis is the entrepreneurship in housing construction in Russia. We will make a brief characterization of construction business in modern conditions.

Russia is greatly yield to almost all countries of Europe in the housing provision—not only Western but

\footnotetext{
Marina Yudenko, Dr. Sci. Ec., Professor, Department of Economics and Management in Construction, Engineering Faculty of Economics, Saint-Petersburg State University of Economics.

Nadegda Polovnikova, Ph.D., Associate Professor, Department of Economics and Management in Construction, Engineering Faculty of Economics, Saint-Petersburg State University of Economics.

Igor Fedoseev, Dr. Sci. Ec., Professor, Department of Economics and Management in Construction, Dean of Faculty of State and Municipal Management, Saint-Petersburg State University of Economics.

Correspondence concerning this article should be addressed to Marina Yudenko, Saint-Petersburg State University of Economics, Saint-Petersburg, Russia. E-mail: mnuspb@mail.ru
} 
also Eastern. Housing shortage is a major social problem and an important component of economic backwardness of Russia. To achieve at least the modest housing security of Russian citizens—one room per person - country's housing fund is needed to increase by 1.5 times. About 1 sq.m. housing per year per capita would have to be built in the next 10 years to do this, even without considering the disposal, approaching the level of the U.S., Germany, and in recent years China.

The authors note several factors, which contribute to such state of housing construction. They are the low infrastructural density of development areas, big administrative barriers to registration of ownership for land plots, a great number of various permits (over 200) and statutory documents, which regulate construction. All of these factors eventually lead to high transaction costs born by participants of investment-construction cycle.

\section{Research Issues}

The authors suggest addressing the following issues:

(1) to analyze factors, which hinder entrepreneurship activity in housing construction;

(2) to determine the importance of the principle of institutionalism, which introduced in economics such notions as "transaction costs", "uncertainty", "paid-for information", and "opportunism";

(3) to propose the classification of transaction costs taking into account particular aspects of construction industry in Russia;

(4) to emphasize the importance of opportunism in interactions of participants of housing construction.

\section{Research Methods}

Scientific methods (analysis and comparison) and approaches (neo-institutional and socio-economic) employed to obtain the results set out in this article ensure their validity and accuracy. Due to acknowledgement of paid-for information, neo-institutionalism introduces in the analysis the brand new class of costs - transaction costs. Entrepreneurs strive to minimize costs and maximize profit. It is clear how to reduce transformational costs - one should use more productive machinery and improve labour management, whereas reduction of transaction costs is quite problematic. An exacerbating division of labour accompanies the growth of this class of costs.

As the initial scientific hypothesis the authors assume that modern conditions are characterized by a negative index of entrepreneurs' confidence, big percentage of loss-making organizations ( $23 \%$ of total number of organizations), and by the decrease of the share of investments in the fixed assets in construction industry (in 2013-84\%, as compared to 2012). In such conditions the existing institutional infrastructure of construction industry does not meet the market requirements and does not ensure the necessary growth of economic efficiency of entrepreneurial activity in the housing construction.

\section{Research Results}

A natural question arises-what factors prevent the development of housing construction in Russia and limit it. Low value of the index indicates that certain barriers exist in construction activity for entrepreneurs. As in 2007-2013 rates of growth of all key indicators decreased we think that it is necessary to define factors that restrict business activity of construction organizations. Further we will examine this factors more closely (see Table 1).

Table 1 shows that the main limiting factor, according to the entrepreneurs, is the lack of institutional rules 
governing their activities.

In his message to the Federal Assembly in 2013, President Putin V. drew attention to the need to restore order to the approval procedures for construction, which are still not standardized. It is necessary to establish a single, comprehensive list of authorization documents for construction, extremely reduce the time necessary procedures, and do it before the end of March 2014. Such list would reduce transaction costs in construction. The expenditures on overcoming licensing procedures are the main cost item for builders.

Table 1

Distribution of Organizations Over the Factors Restricting Business Activities of Construction Firms (Percentage of Total Number of Organizations)

\begin{tabular}{|c|c|c|c|c|c|c|}
\hline Factor & Type of factor & 2007 & 2008 & 2009 & 2010 & 2011 \\
\hline High level of taxation & Financial & 42 & 43 & 40 & 39 & 45 \\
\hline Insolvency of customer & Economic & 27 & 24 & 42 & 37 & 27 \\
\hline Lack of orders & Economic & 12 & 11 & 27 & 26 & 19 \\
\hline High interest for commercial credits & Commercial & 13 & 11 & 18 & 17 & 11 \\
\hline $\begin{array}{l}\text { Inadequate legal framework and uncertainty } \\
\text { of economic climate }\end{array}$ & Institutional & 11 & 25 & 38 & 42 & 45 \\
\hline
\end{tabular}

Economic entities, incurring certain costs, are not even aware that these costs are transactional and depend on how effectively formed institutions regulating, coordinating, and limiting entrepreneurial activity. Such costs are attributed to production costs and perceived as unavoidable costs of economic entities' activities. There are quite a number of concepts of transaction costs, for example, "costs for the exchange of property rights", "costs of implementation and protection of contracts", "costs of obtaining the benefits from specialization and labor division", and "costs of coordination and motivation activity of economic agents". According to some estimates in a modern market economy transaction costs amount to $50 \%$ of net national income. Such costs are accounted for in cost of construction products and cause unnecessarily high cost of products acquisition for the consumer.

It should be noted that certain steps have being taken to reduce the transaction costs of entrepreneurs in the sphere of construction in Russia. In 2012 the roadmap "Improvement of the business climate in the construction industry" was adopted. Implementation of the roadmap aims to improve the entrepreneurial climate in the sphere of construction, including simplify and improve the administrative procedures at all stages of construction implementation, starting from the preparation of town-planning documentation to commissioning of capital construction objects. The objectives of the roadmap are:

- reducing the number of procedures required for the implementation of investment and construction projects;

- reduction of the total time to complete all the administrative procedures during the implementation of investment and construction projects;

- reduction of expenses required to complete all administrative procedures during the implementation of investment and construction projects.

Doing business rating, prepared annually by the World Bank, was selected as a benchmark of the successful implementation of the roadmap. An entry of the Russian Federation in the top 20 of this rating was elected as a target point of implementation of the roadmap. Some of the indicators are shown in Table $2^{1}$.

\footnotetext{
${ }^{1}$ Government Order (2012) "On approval of action plan improvement of the business climate in the construction industry".
} 
Table 2

Indicators of Successful Implementation of the Roadmap

\begin{tabular}{|c|c|c|c|c|}
\hline Name of benchmark & Measure & 2012 & 2015 & 2018 \\
\hline Position in doing business rating in terms of obtaining a construction permit: & - & 178 & 78 & 34 \\
\hline - number of procedures required to obtain a construction permit & piece & 51 & 15 & 11 \\
\hline $\begin{array}{l}\text { - set of time required to go through all the stages of the procedures } \\
\text { of obtaining a construction permit }\end{array}$ & day & 423 & 130 & 56 \\
\hline
\end{tabular}

There exist a fair number of notions related with transaction costs, e.g., "cost of property rights exchange", "cost of performance and protection of contracts", "cost of gains from specialization and division of labour", "cost of economic agents' coordination and motivation". North (1997) considered it possible to interpret these notions in Marxian terms: Production costs are those determined by the condition of means of production; the character of relations of production determines transaction costs.

Williamson (1996) wrote that it is practical to distinguish between ex ante and ex post transaction costs. The former include expenses for preparation of the draft contract, for negotiations and for securing guarantees of the contract realization. The latter, ex post costs for contract realization, arise as a result of very tangible constraints, to which the mechanism of court settlement of disputes is susceptible.

The most concise and clear definition of transaction costs was given by Eggertsson (2001), who determined transaction costs as costs arising when exchange of individuals' property rights and protection of their exclusive rights takes place.

Furuboth and Richter (2005) set three main types of transaction costs: market transaction costs, management transaction costs, and political transaction costs. Each type can be then subdivided into two: (1) "permanent" transaction costs, viz., specific investments in creation of institutional set-ups; and (2) "variable" transaction costs, which depend on the number or the volume of transactions. Market, management, and political transaction costs can be classified in greater detail as follows:

Market transaction costs include:

- expenses for preparation of contracts (search costs and information costs in a narrow sense);

- expenses for concluding of contracts (negotiation costs and decision costs);

- expenses for monitoring and securing guarantees of performance of contract obligations.

Management transaction costs include:

- expenses for creating, maintaining, and changing of organizational set-up;

- organization operational expenses (information costs and costs, connected with goods and services physical crossing of the border between adjacent production processes).

Political transaction costs are limited to the following types:

- costs of creating, maintaining, and changing of formal and informal political set-up of the system;

- costs of operation of the state system.

In this article the authors offer the classification of transaction costs in housing construction (see Figure 1) taking into account the interconnection whereof with methodological rules of neo-institutionalism.

The above classifications of transaction costs suggest a conclusion that all of them play an important part in various spheres of entrepreneurial activity. The topicality of any given classifications depends on the particular features of the sphere of entrepreneurial activity and on the possibility of practical evaluation of transaction costs. 


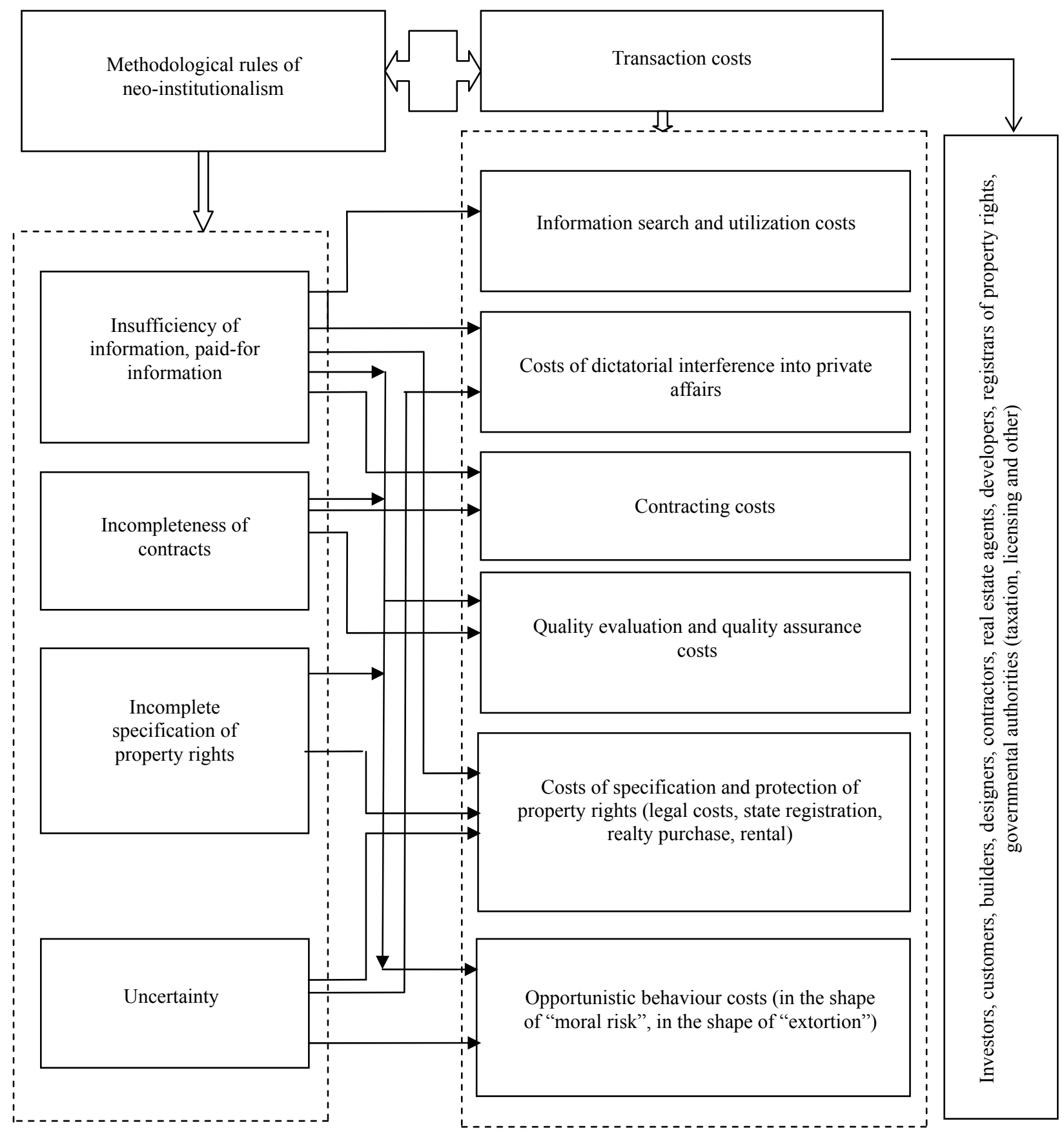

Figure 1. Structure of transaction costs in construction industry.

According to Figure 1, there exist such transaction costs, which are included by scientists in a separate group- “opportunistic behaviour costs". They currently constitute a considerable part of transaction costs and are closely connected with uncertainty. Opportunistic behavior in this article is understood to be any evasion of compliance with the terms of a contract or oral agreement. Therefore employees' non-fulfillment of their obligations and contempt of the lawful orders of the company administration can be considered the same form of opportunistic behavior as supply of defective product.

Williamson (1996) singles out two main forms of opportunistic behaviour. One is called "moral risk", the 
other- "extortion". "Moral risk" arises when a contract party relies on the other party while obtaining credible information about its behavior is either very costly or impossible. This is the most concealed and the most interesting, from the economic theory standpoint, element of transaction costs, to which authors refer costs, connected first of all with more or less disguised evasion (but not a direct refusal from fulfillment) of obligations undertaken by the parties to the contract. An illustration of "moral risk" is a lazing around employee, who does not fulfill his duties well. Revealing of such facts often requires from administration development of expensive but ineffective control systems. Nevertheless, reduction of such kind of costs is just one of the managerial tasks. Another example of such costs is a partner's deliberate non-fulfillment of his contractual obligations.

Opportunistic behaviour costs also include expenses, connected with extortion. Extortion is understood to be a situation when doing business is possible for technological or other reasons only upon availability of certain factors. If one of these factors is withdrawn from the overall process, as a result all other economic entities can sustain heavy losses.

Opportunistic behaviour is common to all participants of construction process. Civil engineering is a complicated and lengthy process, which involves a big number of participants_investors, builders, designers, contractors and others. Opportunistic behavior is common to all of them. Costs, connected with such behavior eventually lie on consumers of construction products, to whom opportunism is also relevant.

The principal way of their reduction is, in our opinion, lessening of environmental uncertainty at the expense of stable and effective social institutes. These institutes, from a neo-institutionalism perspective, on the one hand, are exogenous constraints on entrepreneurial activity, and on the other, create conditions for efficient entrepreneurship.

Opportunistic behaviour should be distinguished from breach of agreement. Opportunism can justify the fact that behaviour, which does not infringe the obvious terms of a contract, is called breaching. At the same time not every breach of agreement is opportunistic behaviour. For example, a party can benefit from the breach of the contract so much that it will be able to compensate the other party losses, caused by this breach, and still remain in profit. Such situation can occur if, for example, changed circumstances raise the cost of the contract performance (e.g., increase of price for component parts or labour). Non-fulfillment of the contract will enable the debtor to save costs and these savings will exceed the creditor's losses from the breach of the contract. This case lacks opportunistic behavior since redistribution of wealth from the creditor to the debtor does not take place - the debtor will compensate losses, which the creditor sustained due to the breach of the contract. Redistribution of wealth is a necessary condition for a certain behavior to be called opportunistic. However a party to a contract - "the victim of opportunistic behavior" should have the legal right for the part of wealth, which this party loses as a result of opportunistic behavior of the other party.

\section{Analysis}

Situations when a breach of agreement is linked with opportunistic behaviour occur quite often in entrepreneurs' economic activity. Some data is cited below:

(1) In 2013 arbitration courts investigated 684,797 cases of non-fulfilment or negligent performance of contractual obligations, which is $5.7 \%$ more than in 2012. In the same year they handled 71,887 cases of non-fulfilment of contracts for work and labour, which is $15.9 \%$ more than in 2012 . The increase in number of cases of non-fulfilled contracts for work and labour happened due to a $20 \%$ growth in number of cases related 
to non-fulfilment or negligent performance of construction contracts. To a certain extent this growth was caused by the fast pace of construction within the programs (including those of social orientation) undertaken by administrations of various regions of the country. A large-scale project of holding XXII winter Olympic Games in Sochi should be also mentioned here. Implementation of such programs requires heavy expenditures and tight schedule of works and therefore leads to multiple legal disputes in the long chain of relations between customer and contractor, contractor and subcontractor.

(2) In 2013 there were considered 13,474 cases of conclusion, amendment and termination of contracts as well as 14,016 cases of contract nullification.

(3) In accordance with the Federal Law of 26.10.2002 "On Declared Insolvency (Bankruptcy)", in 2013 arbitration courts handled 31,625 claims within developers' bankruptcy cases. The share of such claims in the total number of considered applications, complaints, and petitions constituted $13.2 \%$.

\section{Conclusions}

As a closing remark we would note that the main way to reduce transaction cost is lessening of environmental uncertainty at the expense of stable and effective social institutes. Such institutes, from a neo-institutionalism perspective, on the one hand, are exogenous constraints on entrepreneurial activity, and on the other hand, create conditions for efficient entrepreneurship in construction industry.

Conclusions are drawn as follows:

(1) Entrepreneurs are not able to reduce transaction costs and consequently housing costs without the state regulation of housing construction process and without development of institutional rules to regulate the activity of multiple participants of construction process.

(2) Indeed, the legislative framework of Russian market economy progressed considerably over the last years. However, practical application of laws is not that successful. The laws are not always obeyed. This practice is typical of both vertical (state-entrepreneurs) and horizontal relations (between entrepreneurs themselves - subjects of the investment and construction complex), which means that it is typical of relations, called "contracts".

(3) Institutional discipline of relations between participants of construction process has to be improved, which will subsequently translate into reduction of transaction costs, that is of entrepreneurs' additional costs and efforts spent to individually protect their rights and interests, although protection of "contracts" is one of the main tasks of the state in economics. This state function is so absolute that it should be perceived by the participants of economic relations as a matter of course.

(4) Obviously inefficient performance by the Russian state authorities of their function to protect contracts is linked with the defects in the legislative framework and judicial system organization. The fact that many official organizations create such limitations for entrepreneurs, which suppress business activity of a number of civilized economic entities, is testimony to the weakness of institutes in the law-governed state, real dominance of executive authorities over other governmental departments, lack of traditions and real conditions for independence of judicial power.

(5) Presently the state exhibits its activity as a rule-maker. At the same time it is important that the state itself acts in compliance with the laws, made. Not every law can be an institute or an observable norm. The more rules and norms meet the interests of those for whom they are made, the better they are observed. Only in this case they reduce transaction costs of opportunistic behavior control of the subjects of investment and 
construction complex. Investment and construction practice has many forcefully imposed norms. Such approach is utterly ineffective, because it requires a lot of means to ensure that these norms are obeyed. In order that the law becomes a "strong institute", the state should strive to work out a compromise between conflicting interests of the parties. This is its intended purpose.

\section{References}

Construction complex of Russia in 2012. (2014). Statistical bulletin. Retrieved from http://www.gks.ru/

Eggertsson, T. (1990). Economic behavior and institutions. Britain: Publishing house of Cambridge University Press.

Furuboth, E. G., \& Richter, R. (2005). Institutions economic theory: The contribution of the new institutional economics. Saint Petersburg: Publishing house of Saint Petersburg State University.

North, D. (1997). Institutions, institutional change and economic performance. Britain: Publishing house of Cambridge University Press.

Willamson, O. E. (1996). The economic institutions of capitalism: Firms, markets, relational contracting. Saint Petersburg: Lenizdat, CEV Press.

Yudenko, M. N. (2008). Theory and methodology of entrepreneurship structure development: Neo-institutional approach: monograph. Saint Petersburg: Saint Petersburg State University of Economics.

Yudenko, M. N., \& Ilina, A. A. (2012). Transaction costs as a deterrent to investment and construction complex development. Science and Economics, 5(13), 5-11. 